\title{
Physiological and biochemical responses to low non-freezing temperature of two Eucalyptus globulus clones differing in drought resistance
}

\author{
Alla Shvaleva ${ }^{1,2 *}$, Filipe Costa e Silva ${ }^{1}$, Paula Scotti $^{3}$, Mouhssin OufiR ${ }^{4}$, Jean-François \\ Hausman $^{4}$, Guignard Cedric ${ }^{4}$, Paula Ramos ${ }^{3}$, M. Helena Almeida ${ }^{1}$, M. Lucília Rodrigues ${ }^{1}$, \\ João S. Pereira ${ }^{1}$, M. Manuela Chaves ${ }^{2}$ \\ ${ }^{1}$ Instituto Superior de Agronomia, Tapada da Ajuda 1349-017 Lisboa, Portugal \\ ${ }^{2}$ Lab. Ecofisiologia Molecular, ITQB, Apt.127, Oeiras 2781-901, Portugal \\ ${ }^{3}$ Estação Agronomica Nacional, Departamento de Fisiologia Vegetal, Av. República, P-2784-505, Oeiras, Portugal \\ ${ }^{4}$ CRP-Gabriel Lippmann, EVA (Environment and Agriculture), Department 41, rue du Brill, L-4422 Belvaux, GD Luxembourg
}

(Received 22 January 2007; revised version 12 April 2007; accepted 22 August 2007)

\begin{abstract}
We have compared the metabolic responses of leaves and roots of two Eucalyptus globulus L. clones CN5 and ST51 that differ in their sensitivity to water deficits (ST51 is more drought sensitive), with regard to the effect of chilling $\left(10 / 5^{\circ} \mathrm{C}\right.$, day/night). We studied changes in growth, osmotic potential and osmotically active compounds, soluble proteins, leaf pigments, and membrane lipid composition. Our data showed that both clones have the ability to acclimatize to chilling temperatures. As a result of 10 days of acclimation, an increase of soluble sugars in leaves of treated plants of both clones was observed that disappeared later on. Differences between clones were observed in the photosynthetic pigments and soluble protein content which were more stable in CN5 under chilling. It also was apparent that CN5 presented a less negative predawn water potential ( $\left.\psi_{\text {pd }}\right)$ and a higher leaf turgor than ST51 throughout the chilling treatment. In the case of the CN5, increased total lipids (TFA) and concomitant increase of linolenic acid (C18:3) in leaves after acclimatization may be related to a better clone performance under chilling temperatures. Moreover, a higher constitutive investment in roots in the case of CN5 as compared to ST51 may benefit new root regeneration under low temperatures favoring growth after cold Mediterranean winter.
\end{abstract}

carbohydrates / chilling / Eucalyptus globulus L. / lipids / membranes

Résumé - Réponses physiologiques et biochimiques à des températures froides positives de deux clones d'Eucalyptus globulus qui diffèrent à travers leur résistance à la sécheresse. Nous avons comparé les réponses métaboliques au niveau des feuilles et racines de deux clones d'Eucalyptus globules L. CN5 et ST51 qui différent par leur sensibilité à la sécheresse (ST51 étant le plus sensible) en comparaison à l'effet de refroidissement $\left(10^{\circ} \mathrm{C} / 5^{\circ} \mathrm{C}\right.$, jour/nuit). Nous avons étudié les variations de croissance, de potentiel osmotique, des composés actifs osmotiquement, des protéines solubles, des pigments foliaires et de la composition de la membrane lipidique. Nos données ont montré que les deux clones ensemble ont la capacité de s'acclimater aux températures froides. À dix jours d'acclimatation, une augmentation de la teneur en sucres solubles dans les feuilles des plantes traitées des deux clones a été observée jusqu'à disparaître dans le temps. Des différences entre les clones ont été observées au niveau du contenu en pigments photosynthétiques et en protéines solubles qui d'ailleurs ont été plus stables pour le clone CN5 sous l'effet du froid. Il est aussi notable que CN5 a présenté un potentiel hydrique de base $\left(\psi_{\mathrm{pd}}\right)$ moins négatif et une turgescence foliaire plus élevée que ST51 à travers le traitement au froid. Dans le cas du clone CN5, l'augmentation concomitante des acides gras totaux (AGT) et de l'acide linolénique. (C18:3) au niveau des feuilles après l'acclimatation peut être corrélée à une meilleure performance de ce dernier sous des températures froides. De plus, un investissement constitutif plus élevé au niveau des racines dans le cas de CN5 en comparaison à ST51 peut avantager la régénération de nouvelles racines sous des températures basses favorisant la croissance après un hiver méditerranéen froid.

carbohydrates / refroidissement / Eucalyptus globulus L. / lipides / membranes

\section{INTRODUCTION}

Eucalyptus globulus Labill. is an evergreen tree that grows in many regions of winter-rain climates of the Mediterraneantype with a dry and hot summer. In such conditions, a more efficient clone should not only use more water (through deep rooting) but also take advantage of the water availability of the cold season through greater chilling tolerance. Previous

* Corresponding author: shvaleva@itqb.unl.pt studies of two highly productive E. globulus clones, CN5 and ST51, with different sensitivity to drought, indicated that these clones exhibited different strategies to cope with water deficit [6]. The investment in root system development before drought, a continuous greater root growth and higher xylem hydraulic conductance under water stress explained superior drought resistance of CN5 clone compared with ST51 clone. Under gradual subjection to water stress both clones CN5 and ST51 had the ability to respond to water deficit at the cellular 
level by altering their osmotic components and the activity of the antioxidant protection system [24].

Eucalyptus globulus is susceptible to cold and does not tolerate below-freezing temperatures [2]. Moreover, growth is limited by chilling temperatures, e.g. from $\left(0{ }^{\circ} \mathrm{C}\right) 4^{\circ} \mathrm{C}$ to $15{ }^{\circ} \mathrm{C}$, which may be too low for normal growth. The plants exposed to chilling temperatures undergo a process of acclimation associated with several physiological and biochemical alterations in the plants $[2,12,25]$. The best-characterized changes under chilling, as well as under different types of stresses, include alterations in gene expression, changes in hormone level, accumulation of osmolytes (compatible solutes) and protective proteins as well as modification of cell membranes [4].

According to previous studies $[13,16]$, the thermotropic phase transition of membrane lipids might play an initiative role in the chilling sensitivity of plants. In chill-sensitive plants, the lipid bilayer has a high percentage of saturated fatty acids chains, and this type of membrane tends to solidify into a semicrystalline state at a temperature well above $0{ }^{\circ} \mathrm{C}$ [27]. As the membranes become less fluid, permeability is affected. During acclimation of plants to low temperature the fatty acids in their membrane lipids become more unsaturated, resulting in enhanced membrane stability $[22,26]$.

In Mediterranean ecosystems, plant performance during winter is poorly studied, maybe because summer-drought constrains are much more conspicuous. However, "cold" is a relative term and even the "mild" temperatures of Mediterranean winters may be too low for plant species which have to cope with wide thermal amplitude over the year. However, climate change scenarios for the western Mediterranean (including Portugal) suggest lengthening of the dry season [15], which may turn plants even more dependent from a relatively cool but shorter rainy season. There is also the possibility that global warming will enhance the frequency of extreme weather events including cold spells [7]. The comparison of the dynamics of physiological and biochemical changes between non-acclimated and acclimated plants, is of the utmost importance to understand stress coping mechanism in trees. Considering that resistance of plants to drought and low temperatures share common mechanisms [25], the aim of the present work was to investigate whether the two clones with contrasting response to drought (CN5 and ST51) also exhibit differences (growth and metabolic) in response to low nonfreezing temperature. We analysed the effect of gradual temperature decrease and the effect of chilling on morphological parameters, membrane lipid composition and compatible solutes in leaves and roots of both clones, as well as osmotic potential, soluble proteins and pigments in leaves.

\section{MATERIAL AND METHODS}

\subsection{Plant material}

Rooted cuttings of the two clones ST51 and CN5 were grown in plastic containers filled with $60 \%$ peat and $40 \%$ styrofoam beads. ST51 is considered more drought sensitive than CN5. After four months the rooted cuttings of both clones were transplanted to $5.3 \mathrm{~L}$ plastic pots. At six months old, 32 plants per clone were transferred from nursery and placed in a growth chamber subjected to a gradual temperature decrease $\left(1.4{ }^{\circ} \mathrm{C}\right.$ per day) from $24 / 16{ }^{\circ} \mathrm{C}$ to $10 / 5{ }^{\circ} \mathrm{C}$ (day/night), which took 10 days (acclimation). Measurements were started at Day 1 after plants had reached $10 / 5^{\circ} \mathrm{C}$, the beginning of the chilling treatment. Another 32 plants per clone remained in control conditions $\left(24 / 16^{\circ} \mathrm{C}\right)$. Air and pot soil temperatures in the growth chamber were monitored through a data logger (DL2e, delta-t Device, UK) to follow temperature changes during the day. It must be taken into account that under natural conditions soil temperature does not vary as rapidly as air temperature. Other growth conditions were: photoperiod: 12/12 h (day/night), relative humidity of approximately $60 \%$, photosynthetic photon flux density: $220 \mu \mathrm{mol} \mathrm{m}^{-2} \mathrm{~s}^{-1}$. The experiment lasted for 52 days ( 7 th January 2005 to 1 st March 2005). All plants were watered to runoff on the first day and then twice per week.

\subsection{Growth analysis and sampling dates}

Plants were harvested 52 days after the beginning of the chilling treatment. Shoots were separated into stem, lateral branches and stem leaves. Roots were gently washed and carefully separated from soil and other debris. Plant components were then dried for at least $48 \mathrm{~h}$ at $80{ }^{\circ} \mathrm{C}$ in the oven and cooled in desiccators for dry mass determination. Leaves and roots were scanned before drying and then leaf and root area of each seedling (five plants per treatment) were calculated with WinRhizo software (Regent Instrument Inc., Canada). Samples for carbohydrates, lipids, proline, soluble protein analyses and osmotic potential were collected on Days 1, 7 and 42 after the beginning of chilling at predawn on full-expanded leaves $(0.5 \mathrm{~g}$ fresh mass $)$ and at midday on root segments $(0.5 \mathrm{~g}$ fresh mass and diameter $<2 \mathrm{~mm}$ ) excised from the central part of the root system, using five plants per treatment. Samples were removed, frozen immediately in liquid nitrogen and kept at $-80{ }^{\circ} \mathrm{C}$ until further analysis.

\subsection{Plant water relations}

Predawn water potential $\left(\psi_{\mathrm{pd}}\right)$ was measured with a Scholandertype pressure chamber (PMS Instruments, Corvallis, OR) on five plants per treatment. From the same plants, leaf discs $(6 \mathrm{~mm}$ diameter) were taken at predawn for osmotic potential $\left(\psi_{\pi}\right)$ determination, frozen in liquid nitrogen and stored at $-80{ }^{\circ} \mathrm{C}$ until analysis. The measurements of $\psi_{\pi}$ were made after thawing the samples at room temperature, using C-52 sample chambers connected to a Wescor HR33 dew-point microvoltmeter (Wescor, INC Logan, UTAH, USA). Leaf turgor $\left(\psi_{\mathrm{p}}\right)$ was calculated according to the equation: $\psi_{\mathrm{p}}=\psi_{\mathrm{pd}}-$ $\psi_{\pi}$. Osmotic potential at full turgor $\left(\psi_{\pi}^{100}\right)$ was calculated from $\psi_{\pi}$ corrected by relative water content values (RWC), measured in samples of 10 leaf discs of $0.7 \mathrm{~cm}$ diameter. RWC was calculated as RWC (\%) $=(\mathrm{FW}-\mathrm{DW}) /(\mathrm{TW}-\mathrm{DW}) \times 100$, where $\mathrm{FW}, \mathrm{TW}$ and $\mathrm{DW}$ are the fresh, turgid (after floating the samples for $3 \mathrm{~h}$ on distilled water at room temperature) and dry mass (after oven-drying at $80^{\circ} \mathrm{C}$ ), respectively.

\subsection{Leaf pigments}

Pigments were extracted from frozen leaf discs as described in Shvalva et al. [24] and then analysed by HPLC according to Wright et al. [32] and quantified by custom-made external standard solutions 

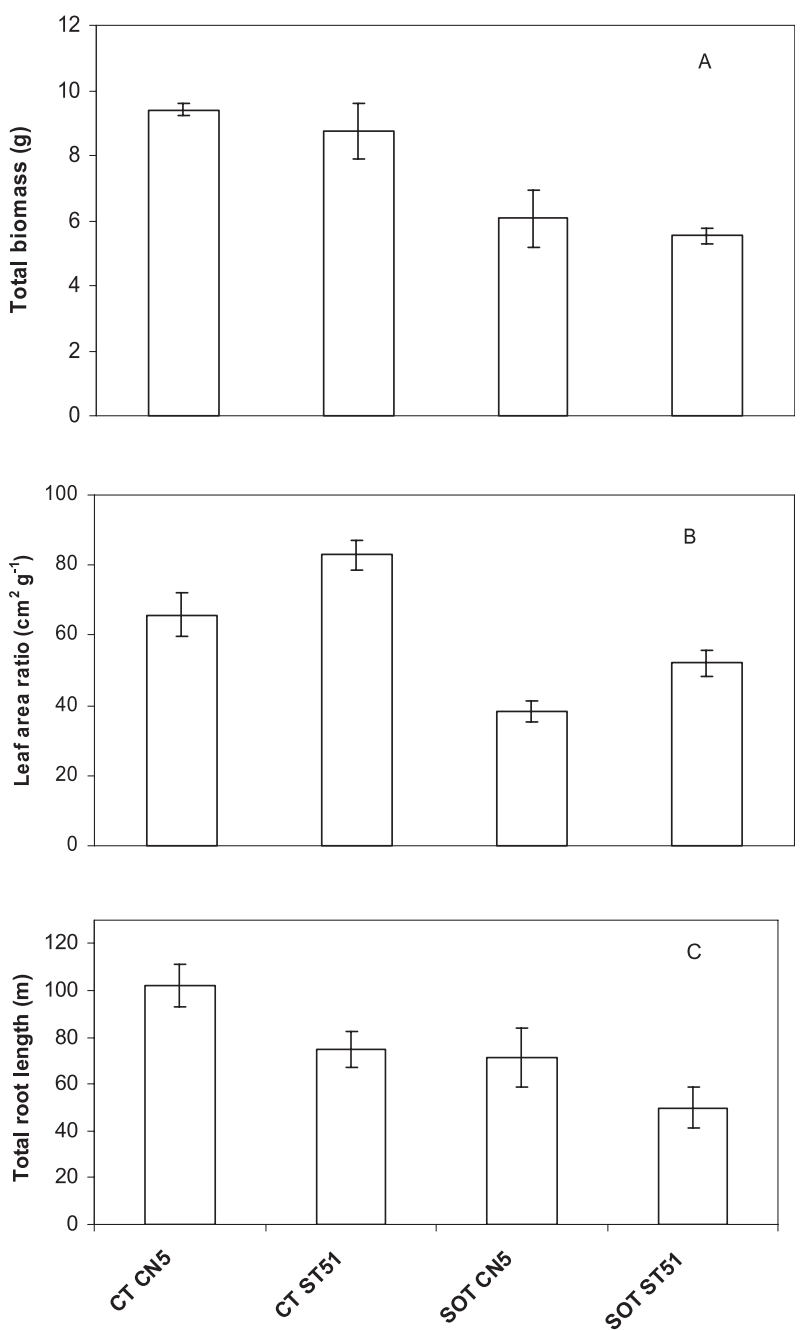

Figure 1. Some morphological characteristics of two Eucalyptus globulus Clones CN5 and ST51 subjected to low temperature treatment: total biomass (g) (A), leaf area ratio $\left(\mathrm{cm}^{2} \mathrm{~g}^{-1}\right)(\mathrm{B})$ and total root lenght $(\mathrm{m})(\mathrm{C})$ evaluated at the end of the experiment $(42 \mathrm{~d}$ after acclimation).

(DHI Water and Environment; Denmark and Carotenature, Switzerland). Twenty-five microliter samples were injected in Zorbax (Agilent Tech., USA) Bonus-RP C18 column and eluted with a quaternary gradient composed of water, acetonitrile, ethyl acetate and $0.5 \mathrm{M}$ ammonium acetate in methanol $(20: 80, \mathrm{v} / \mathrm{v})$ at flow-rate of $1.0 \mathrm{~mL} \mathrm{~min}^{-1}$. Pigments content were measured after 42 days of chilling.

\subsection{Lipid analysis}

For lipid analysis, the general procedure of Pham Thi et al. [20] was used with modification according to Scotti Campos et al. [22]. Lipids were extracted in chloroform/methanol/water $(1 / 1 / 1, \mathrm{v} / \mathrm{v} / \mathrm{v})$ according to Allen et al. [1]. After saponification, fatty acids were methylated with $\mathrm{BF}_{3}$ (Merck) according to Mercalfe et al. [14] using heptadecanoic acid (C17:0) as an internal standard. Subsequently they were analysed by gas-liquid chromatography as described in Mercalfe et al. [22].
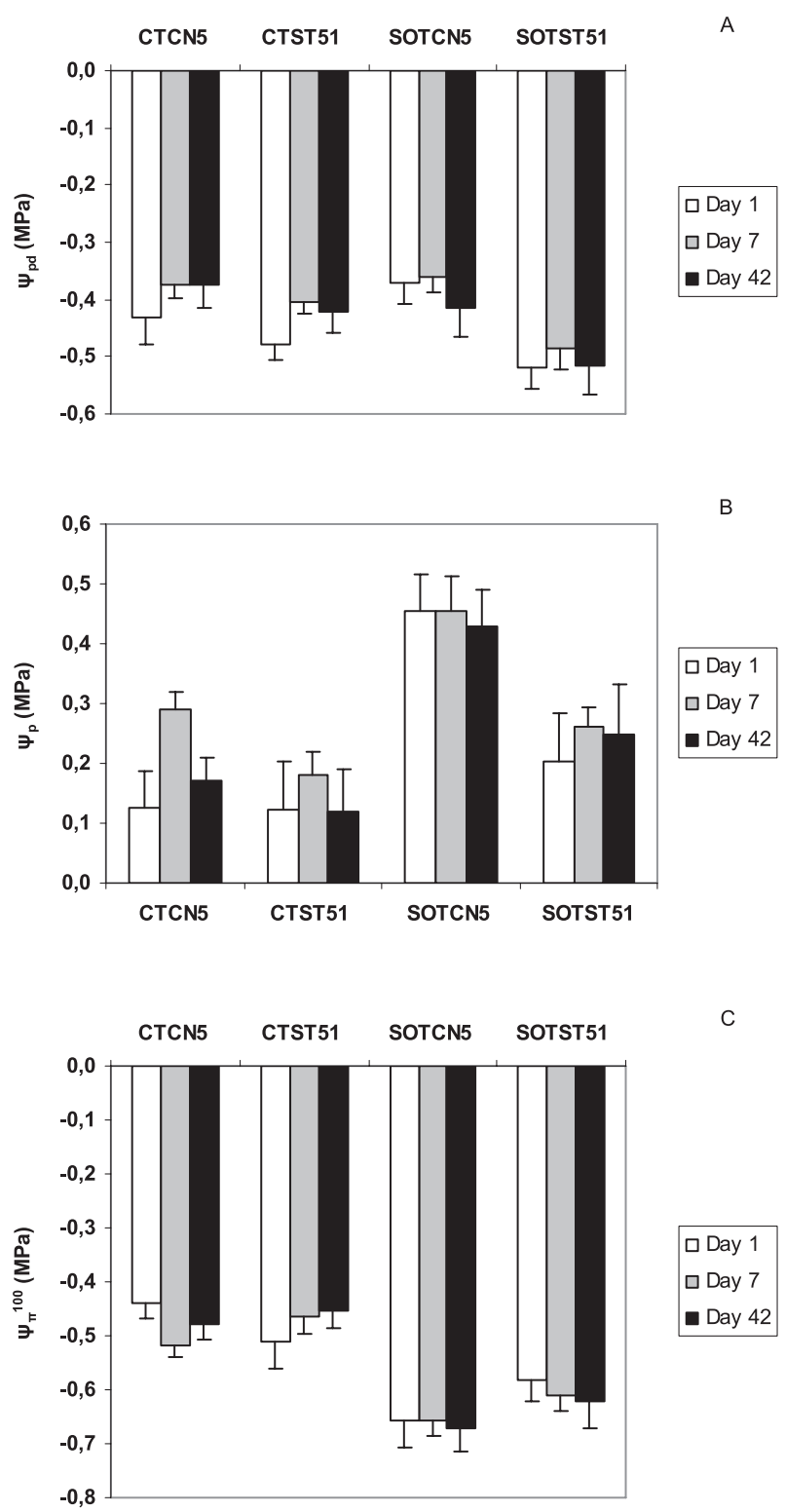

Figure 2. Water potential ( $\left.\psi_{\mathrm{pd}}, \mathrm{A}\right)$ and leaf turgor $\left(\psi_{\mathrm{p}}, \mathrm{B}\right)$, both measured at predawn and osmotic potential at full turgor $\left(\psi_{\pi}^{100}, \mathrm{C}\right)$ in leaves of Eucalyptus globulus Clones CN5 and ST51 at Day 1, 7 and 42 after suboptimal temperature. CT - control $\left(24 / 16^{\circ} \mathrm{C}\right)$, SOT - suboptimal temperature $\left(10 / 5^{\circ} \mathrm{C}\right)$. Values are mean $\pm \mathrm{SE}(n=5)$.

\subsection{Soluble proteins}

Soluble proteins were extracted and measured as detailed in Bradford [3].

\subsection{Carbohydrates and polyols extraction and analysis}

Carbohydrates and polyols were extracted from leaves and roots (100 mg FW), according to Van Huylenbroeck and Debergh [30] and then analysed using High Performance Anion Exchange Chromatography coupled with Pulsed Amperometric Detection HPAEC-PAD 
Table I. Galactose, glucose, sucrose, fructose, arabinose and inositol content ( $\mu \mathrm{mol} \mathrm{g}^{-1}$ dry mass) in leaves of E. globulus Clones CN5 and ST51 after cold acclimation (Day 1), after 7 and 42 days of suboptimal temperature. CT - control (24/16 $\left.{ }^{\circ} \mathrm{C}\right)$, SOT - suboptimal temperature $\left(10 / 5^{\circ} \mathrm{C}\right), * * *, * * *$ Represent statistical significance at $P<0.05,0.01$ and 0.001 , respectively; and ns $=$ nonsignificant at $P=0.05$.

\begin{tabular}{|c|c|c|c|c|c|c|c|}
\hline \multirow{2}{*}{$\begin{array}{l}\text { Days after } \\
\text { acclimation }\end{array}$} & \multirow[b]{2}{*}{ CN5 CT } & \multirow[b]{2}{*}{ ST51 CT } & \multirow[b]{2}{*}{ CN5 SOT } & \multirow[b]{2}{*}{ ST51 SOT } & \multicolumn{3}{|c|}{ Two-way ANOVA } \\
\hline & & & & & Clone $(\mathrm{C})$ & Temp. (T) & $\mathrm{C} \times \mathrm{T}$ \\
\hline \multicolumn{8}{|l|}{$\overline{\text { Day } 1}$} \\
\hline Galactose & $1.5 \pm 0.2$ & $1.0 \pm 0.1$ & $1.6 \pm 0.2$ & $1.5 \pm 0.2$ & ns & ns & ns \\
\hline Glucose & $6.3 \pm 0.6$ & $4.2 \pm 0.4$ & $10.8 \pm 1.5$ & $6.81 \pm 0.9$ & $* *$ & $* *$ & ns \\
\hline Sucrose & $1.9 \pm 0.4$ & $0.7 \pm 0.2$ & $6.1 \pm 1.2$ & $3.0 \pm 0.5$ & $* *$ & $* * *$ & ns \\
\hline Fructose & $6.8 \pm 0.6$ & $5.9 \pm 1,2$ & $12.0 \pm 0.7$ & $7.6 \pm 1.0$ & $* *$ & $* *$ & ns \\
\hline Arabinose & $0.12 \pm 0.02$ & $0.09 \pm 0.02$ & $0.15 \pm 0.02$ & $0.15 \pm 0.03$ & ns & ns & ns \\
\hline Inositol & $16.1 \pm 3.1$ & $20.9 \pm 2.1$ & $16.0 \pm 2.9$ & $10.5 \pm 1.9$ & ns & 0.06 & 0.06 \\
\hline \multicolumn{8}{|l|}{$\overline{\text { Day } 7}$} \\
\hline Galactose & $1.2 \pm 0.05$ & $1.2 \pm 0.1$ & $1.6 \pm 0.2$ & $1.5 \pm 0.1$ & ns & $*$ & ns \\
\hline Glucose & $7.8 \pm 0.5$ & $7.3 \pm 1.6$ & $16.8 \pm 4.3$ & $14.9 \pm 2.4$ & ns & $* *$ & ns \\
\hline Sucrose & $2.2 \pm 0.5$ & $1.9 \pm 0.7$ & $9.1 \pm 2.6$ & $7.1 \pm 0.6$ & ns & $* *$ & ns \\
\hline Fructose & $6.3 \pm 0.4$ & $5.3 \pm 0.9$ & $12.7 \pm 0.8$ & $10.5 \pm 0.9$ & 0.06 & $* * *$ & ns \\
\hline Arabinose & $0.07 \pm 0.01$ & $0.11 \pm 0.03$ & $0.14 \pm 0.01$ & $0.11 \pm 0.01$ & ns & ns & ns \\
\hline Inositol & $20.0 \pm 1.1$ & $20.7 \pm 1.8$ & $14.2 \pm 1.0$ & $12.2 \pm 0.5$ & ns & $* * *$ & ns \\
\hline \multicolumn{8}{|l|}{$\overline{\text { Day } 42}$} \\
\hline Galactose & $1.4 \pm 0.1$ & $2.3 \pm 0.3$ & $1.6 \pm 0.1$ & $1.5 \pm 0.2$ & ns & ns & $*$ \\
\hline Glucose & $5.5 \pm 0.5$ & $8.1 \pm 0.8$ & $12.5 \pm 4.0$ & $9.6 \pm 1.9$ & ns & ns & ns \\
\hline Sucrose & $1.8 \pm 0.4$ & $2.5 \pm 0.5$ & $9.2 \pm 3.6$ & $6.0 \pm 1.2$ & ns & $*$ & ns \\
\hline Fructose & $5.2 \pm 0.8$ & $6.7 \pm 0.9$ & $11.9 \pm 0.9$ & $10.2 \pm 0.7$ & ns & $* * *$ & ns \\
\hline Arabinose & $0.11 \pm 0.05$ & $0.15 \pm 0.02$ & $0.16 \pm 0.02$ & $0.15 \pm 0.02$ & ns & ns & ns \\
\hline Inositol & $10.6 \pm 1.3$ & $22.8 \pm 0.5$ & $18.8 \pm 1.6$ & $19.7 \pm 2.9$ & $* *$ & ns & $* *$ \\
\hline
\end{tabular}

(Dionex ED 40, Dionex Corp., USA) according to Wilson et al. [31]. The analytical column for carbohydrates was a Dionex Carbopac PA$20(3 \mathrm{~mm} \times 150 \mathrm{~mm}) \mathrm{kept}$ at $30^{\circ} \mathrm{C}$ and eluted by on on-line generated $\mathrm{KOH}$ at $0.5 \mathrm{ml} \mathrm{min}{ }^{-1}$, whereas polyols were analysed on Dionex Carbopac MA-1 $(4 \mathrm{~mm} \times 250 \mathrm{~mm})$ stored at $48^{\circ} \mathrm{C}$ and eluted by a gradi-

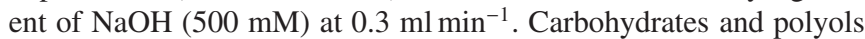
were quantified using calibration curves with standard solutions [10].

\subsection{Proline and proline analogues extraction and analysis}

Approximately $100 \mathrm{mg}$ of fresh plant material was extracted according to Naidu [17] and then analysed using High Performance Ligand-Exchange Chromatography coupled with Mass Spectrometry HPLEC-MS. N-acetyl DL-proline (Sigma-Aldrich Chemical Company) was used as internal standard [18].

\subsection{Data analysis}

Data were subjected to two-way analysis of variance (ANOVA) to test for the effects and interactions of temperature treatment and between clones, using the STATISTICA (Version 6, 2001, StatSoft, Tulsa, OK) data analysis software system. Data are shown as the mean \pm SE in tables and figures. All statistically significant differences between treatments were tested at the $P<0.05$ level.

\section{RESULTS}

\subsection{Growth response}

Forty-two days of chilling had a negative effect on growth of both clones with reductions of total biomass, leaf area ratio and total root length (ca. 35\%, 40\% and 30\%, respectively), in relation to control values (Fig. 1). At the end of the experiment, ST51 plants showed significantly higher $(P<0.01)$ values of leaf area ratio than CN5 plants, whereas the CN5 clone exhibited greater total root length in both treated and control plants.

\subsection{Plant water relation}

Predawn water potentials $\left(\psi_{\mathrm{pd}}\right)$ were maintained stable throughout the experiment, varying between -0.36 MPA and $-0.53 \mathrm{MPa}$ (Fig. 2A). Under low temperatures clone ST51 had more negative $\psi_{\mathrm{pd}}$ than clone CN5 $(P<0.05)$. Control plants maintained leaf osmotic potentials around $-0.58 \mathrm{MPa}$, whereas under low temperature $\psi_{\pi}$ declined significantly $(P<$ 0.01 ) in both clones to $-0.85 \mathrm{MPa}$ and $-0.77 \mathrm{MPa}$ in CN5 and ST51 plants, respectively. So, leaf turgor $\left(\psi_{\mathrm{p}}\right)$ in both clones increased significantly $(P<0.01)$ during chilling (Fig. 2B). The decrease of $\psi_{\pi}$ was a consequence of leaf osmotic adjustment, which mean degree $\left(\Delta \psi_{\pi}^{100}=\psi_{\pi}^{100}\right.$ control $-\psi_{\pi}^{100}$ low temperature) throughout the experiment was of $0.18 \mathrm{MPa}$ and $0.13 \mathrm{MPa}$ for CN5 and ST 51 clones, respectively (Fig. 2C).

\subsection{Carbohydrates in leaves}

Acclimation led to a clear increase in the content of glucose (Glu), sucrose (Suc) and fructose (Fru) in leaves of both clones (Tab. I). There were significant differences between the 
Table II. Galactose, glucose, sucrose, fructose and inositol content ( $\mu \mathrm{mol} \mathrm{g}{ }^{-1}$ fresh mass) in roots of E. globulus Clones CN5 and ST51 after cold acclimation (Day 1), after 7 and 42 days of sub-optimal temperature. CT - Control $\left(24 / 16{ }^{\circ} \mathrm{C}\right)$, SOT - suboptimal temperature $\left(10 / 5{ }^{\circ} \mathrm{C}\right)$. $*, * *, * * *$ Represent statistical significance at $P<0.05,0.01$ and 0.001 , respectively; and ns $=$ nonsignificant at $P=0.05$.

\begin{tabular}{|c|c|c|c|c|c|c|c|}
\hline \multirow{2}{*}{$\begin{array}{l}\text { Days after } \\
\text { acclimation }\end{array}$} & \multirow[b]{2}{*}{ CN5 CT } & \multirow[b]{2}{*}{ ST51 CT } & \multirow[b]{2}{*}{ CN5 SOT } & \multirow[b]{2}{*}{ ST51 SOT } & \multicolumn{3}{|c|}{ Two-way ANOVA } \\
\hline & & & & & Clone $(\mathrm{C})$ & Temp. (T) & $\mathrm{C} \times \mathrm{T}$ \\
\hline \multicolumn{8}{|l|}{$\overline{\text { Day } 1}$} \\
\hline Galactose & $0.78 \pm 0.3$ & $0.41 \pm 0.2$ & $0.49 \pm 0.11$ & $0.91 \pm 0.16$ & ns & ns & ns \\
\hline Glucose & $1.97 \pm 0.73$ & $0.26 \pm 0.12$ & $1.17 \pm 0.45$ & $2.82 \pm 0.46$ & ns & $*$ & $* *$ \\
\hline Sucrose & $1.1 \pm 0.42$ & $0.69 \pm 0.38$ & $1.55 \pm 0.49$ & $2.29 \pm 0.4$ & ns & $*$ & ns \\
\hline Fructose & $0.52 \pm 0.1$ & $0.21 \pm 0.13$ & $0.44 \pm 0.06$ & $0.71 \pm 0.18$ & ns & ns & $*$ \\
\hline Inositol & $0.21 \pm 0.04$ & $0.12 \pm 0.06$ & $0.13 \pm 0.02$ & $0.23 \pm 0.05$ & ns & ns & $*$ \\
\hline \multicolumn{8}{|l|}{$\overline{\text { Day } 7}$} \\
\hline Galactose & $0.19 \pm 0.03$ & $0.33 \pm 0.1$ & $1.45 \pm 0.5$ & $0.38 \pm 0.08$ & ns & $*$ & $*$ \\
\hline Glucose & $0.27 \pm 0.05$ & $0.43 \pm 0.13$ & $2.67 \pm 1.31$ & $1.42 \pm 0.67$ & ns & $*$ & ns \\
\hline Sucrose & $0.19 \pm 0.05$ & $0.28 \pm 0.08$ & $2.17 \pm 1.18$ & $1.46 \pm 0.57$ & ns & $*$ & $\mathrm{~ns}$ \\
\hline Fructose & $0.18 \pm 0.03$ & $0.33 \pm 0.05$ & $0.83 \pm 0.42$ & $0.65 \pm 0.15$ & $\mathrm{~ns}$ & $*$ & ns \\
\hline Inositol & $0.09 \pm 0.02$ & $0.05 \pm 0.01$ & $0.36 \pm 0.13$ & $0.24 \pm 0.06$ & ns & $* *$ & ns \\
\hline \multicolumn{8}{|l|}{ Day 42} \\
\hline Galactose & $0.23 \pm 0.08$ & $0.21 \pm 0.05$ & $1.3 \pm 0.4$ & $0.85 \pm 0.24$ & ns & $* *$ & ns \\
\hline Glucose & $0.63 \pm 0.2$ & $0.5 \pm 0.16$ & $2.94 \pm 0.72$ & $2.98 \pm 0.98$ & ns & $* * *$ & ns \\
\hline Sucrose & $0.27 \pm 0.05$ & $0.41 \pm 0.17$ & $3.26 \pm 0.48$ & $2.82 \pm 0.64$ & ns & $* * *$ & $\mathrm{~ns}$ \\
\hline Fructose & $0.51 \pm 0.08$ & $0.74 \pm 0.05$ & $1.29 \pm 0.24$ & $1.02 \pm 0.15$ & $\mathrm{~ns}$ & $* * *$ & $\mathrm{~ns}$ \\
\hline Inositol & $0.21 \pm 0.03$ & $0.19 \pm 0.04$ & $0.92 \pm 0.28$ & $0.70 \pm 0.28$ & ns & $* *$ & ns \\
\hline
\end{tabular}

clones $(P<0.01)$ with higher values of these carbohydrates in CN5 plants. After 7 days of chilling in addition to the accumulation of Glu, Suc and Fru, galactose was also significantly higher in both clones as compared to controls. On the contrary, the content of inositol significantly decreased $(P<0.001)$. After 42 days of chilling, the accumulation of Suc and Fru persisted in both clones, although with no significant differences between clones. Among the accumulated carbohydrates Suc showed the highest increases throughout the experiment, whereas arabinose displayed very low contents and without significant changes with the chilling treatment.

\subsection{Carbohydrates in roots}

Acclimation led to a significant $(P<0.05)$ increase of root Glu (10-fold) and Suc (3-fold) content in ST51 plants (Tab. II). After 7 days, chilling led to a significant $(P<0.05)$ increase of all carbohydrates in both clones but more evident in CN5. After 42 days of chilling the increase of carbohydrates $(P<0.01)$ was also observed in both clones. Among the accumulated carbohydrates Suc showed the highest increases at Day 42: 13fold and 7-fold in CN5 and ST51, respectively as compared to controls.

\subsection{Soluble proteins in leaves}

There were no significant changes in soluble proteins in leaves until Day 42 (Fig. 3). After 42 days of chilling, soluble protein content decreased $(P<0.001)$ in both ST51 and CN5 clones (ca. $84 \%$ and $27 \%$, respectively) as compared to controls.

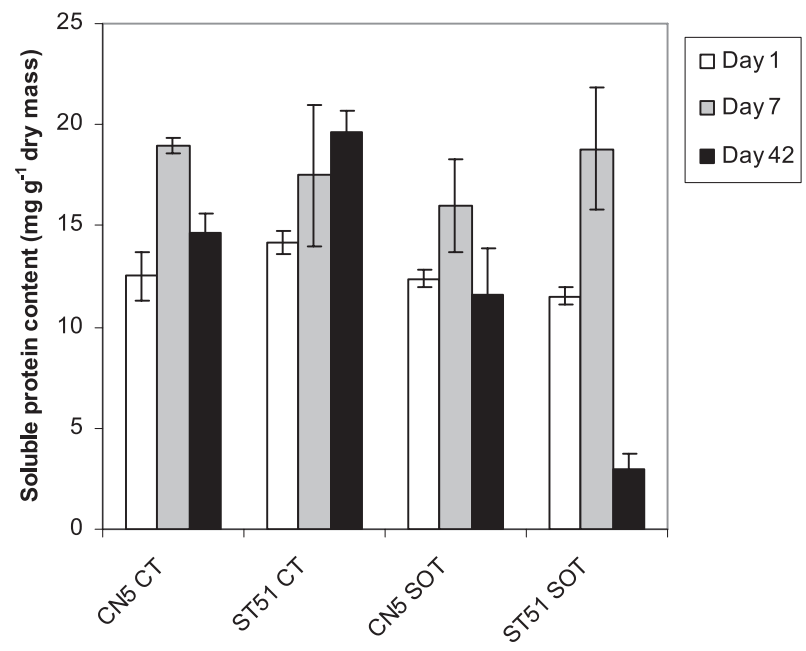

Figure 3. Soluble proteins content ( $\mathrm{mg} \mathrm{g}^{-1}$ dry mass) in leaves of Eucalyptus globulus Clones CN5 and ST51 at Day 1, 7 and 42 after suboptimal temperature. CT - control $\left(24 / 16^{\circ} \mathrm{C}\right)$, SOT - suboptimal temperature $\left(10 / 5^{\circ} \mathrm{C}\right)$. Values are mean $\pm \operatorname{SE}(n=5)$.

\subsection{Leaf pigments}

Pigment content showed a statistically significant $(P<$ 0.001 ) temperature effect after 42 days, which led to a reduction on chlorophyll contents. Clone ST51 showed higher reductions of total chlorophyll content than CN5 under low temperatures, ca. $48 \%$ and $22 \%$ in relation to control plants, respectively (Fig. 4A). Fucoxanthine (Fig. 4B), lutein (Fig. 4C) and $\beta$-carotene (Fig. 4D) content in control ST51 plants were significantly higher when compared with control CN5 plants $(110 \%, 138 \%$ and $127 \%$, respectively). Forty-two 

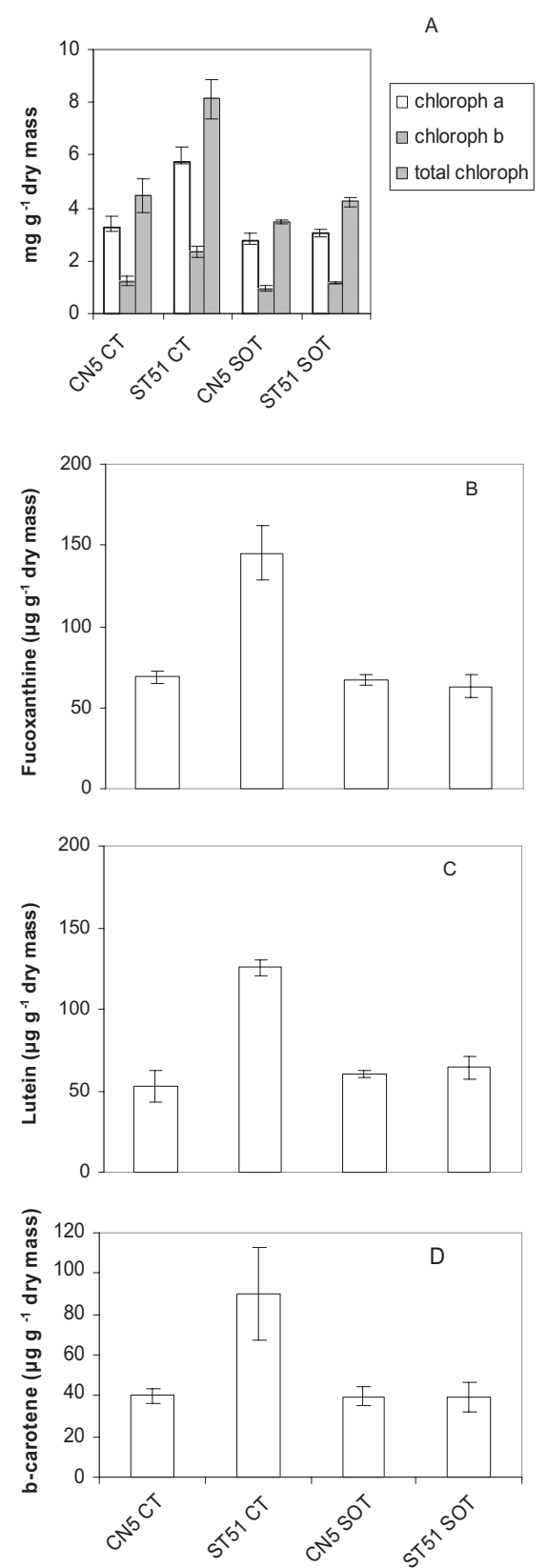

Figure 4. Chlorophyll a, b, total chlorophyll (mg g ${ }^{-1}$ dry mass) (A) and fucoxanthine (B), lutein (C), $\beta$-carotene (D) content $\left(\mu \mathrm{g} \mathrm{g}^{-1}\right.$ dry mass) in leaves of Eucalyptus globulus Clones CN5 and ST51 evaluated after 42 days of chilling. CT - control $\left(24 / 16^{\circ} \mathrm{C}\right)$, SOT - suboptimal temperature $\left(10 / 5{ }^{\circ} \mathrm{C}\right)$. Values are mean $\pm \operatorname{SE}(n=5)$.

days of chilling led to significant reductions of fucoxanthine, lutein and $\beta$-carotene in ST51 plants $(57 \%, 49 \%$ and $57 \%$, respectively), whereas in $\mathrm{CN} 5$ plants no significant changes were observed.

\subsection{Proline and proline analogues in leaves}

Proline content was higher than betaine and trigonelline in leaves of both clones for control and treated plants through- out the experiment (Tab. III). After 7 days under $10 / 5^{\circ} \mathrm{C}$ there was a significant $(P<0.01)$ proline reduction, more evident in ST51 leaves than in CN5 leaves. At Day 42 of chilling trigonelline content showed a significant $(P<0.05)$ reduction in leaves of CN5 and ST51 clones $(63 \%$ and $43 \%$, respectively). There were significant differences between clones $(P<0.05)$ in trigonelline content at Day $1(\mathrm{CN} 5$ had higher content than ST51) and in proline content at Day 42 (ST51 had higher content then CN5).

\subsection{Proline and proline analogues in roots}

Acclimation led to a significant decrease $(P<0.01)$ in betaine root content in CN5 plants but not in ST51 (Tab. IV). After 7 days proline was higher $(P<0.06)$ in plants under low temperature of both clones and trigonelline was significantly higher $(P<0.01)$ in ST51 clone as compared to control plants. Forty-two days of chilling led to decrease (ca. 50\%) in trigonelline in ST51 $(P<0.05)$ without changes in CN5.

\subsection{Lipids in leaves}

Total fatty acid (TFA) content in leaves of control plants of both clones was similar (Tab. V). As a result of acclimation, TFA increased significantly in CN5 (40\%), but not in ST51. After 7 days and 42 days of chilling, TFA content remained stable in both clones. As for the individual fatty acids, at Day 1 clone ST51 presented an increase of $14 \%$ in C18:2 and clone CN5 an increase of 14\% in C18:3 as compared to their respective controls (Tab. V).

After 7 days, chilling led to a significant increase $(P<0.05)$ in C16:0 (20\%) in ST51 leaves and in C18:2 in ST51 and CN5 leaves ( $36 \%$ and $45 \%$, respectively). However, C18:3 was reduced $(P<0.001)$ in both clones (ca. 14\%).

Such a tendency was also observed after forty-two days of chilling. In leaves of ST51, C16:0, significantly increased $(P<$ 0.01) $32 \%$ in comparison with control plants. C18:2 increased by $31 \%$ in leaves of both clones. As for C18:3, it was reduced $15 \%$ in chilling treated ST51 plants and only $6 \%$ in CN5 plants $(P<0.01)$.

Throughout the duration of the experiment no significant changes were observed in C16:1 $t$ in leaves of both clones.

\subsection{Lipids in roots}

No changes of TFA content were observed at Day 1 in roots of both clones (Tab. VI). However, after 7 days and 42 days under low temperatures TFA increased $(P<0.01)$ in CN5 plants (95\% and 69\%, respectively).

In what concerns fatty acids, at Day 1 there was a significant increase $(P<0.01)$ of $\mathrm{C} 18: 3$ in both clones $(29 \%$ and $23 \%$ in ST51 and CN5, respectively). After forty-two days of chilling, C18:2 content increased $12 \%$ in CN5 in roots in relation to control values, while no significant changes occurred in ST51. As for C18:3, a larger increase was observed in roots of ST51 than in roots of CN5 plants (22\% and 8\%, respectively). 
Table III. Proline (nmol g ${ }^{-1}$ dry mass) and proline analogues concentrations in leaves of E. globulus Clones CN5 and ST51 after cold acclimation (Day 1), after 7 and 42 days of suboptimal temperature. CT - control $\left(24 / 16{ }^{\circ} \mathrm{C}\right)$, SOT - suboptimal temperature $\left(10 / 5{ }^{\circ} \mathrm{C}\right) * *, * * * * *$ Represent statistical significance at $P<0.05,0.01$ and 0.001 , respectively; and ns $=$ nonsignificant at $P=0.05$

\begin{tabular}{|c|c|c|c|c|c|c|c|}
\hline \multirow{2}{*}{$\begin{array}{l}\text { Days after } \\
\text { acclimation }\end{array}$} & \multirow[b]{2}{*}{ CN5 CT } & \multirow[b]{2}{*}{ ST51 CT } & \multirow[b]{2}{*}{ CN5 SOT } & \multirow[b]{2}{*}{ ST51 SOT } & \multicolumn{3}{|c|}{ Two-way ANOVA } \\
\hline & & & & & Clone $(\mathrm{C})$ & Temp. (T) & $\mathrm{C} \times \mathrm{T}$ \\
\hline \multicolumn{8}{|l|}{$\overline{\text { Day } 1}$} \\
\hline Proline & $213 \pm 45$ & $145 \pm 40$ & $145 \pm 5$ & $78 \pm 12$ & ns & ns & ns \\
\hline Trigonelline & $94 \pm 15$ & $65 \pm 8$ & $77 \pm 6$ & $50 \pm 7$ & $*$ & ns & ns \\
\hline \multicolumn{8}{|l|}{ Day 7} \\
\hline Proline & $186 \pm 21$ & $155 \pm 27$ & $122 \pm 36$ & $54 \pm 2$ & ns & $* *$ & ns \\
\hline Trigonelline & $74 \pm 5$ & $62 \pm 9$ & $65 \pm 5$ & $62 \pm 9$ & ns & ns & ns \\
\hline \multicolumn{8}{|l|}{ Day 42} \\
\hline Proline & $110 \pm 6$ & $157 \pm 17$ & $90 \pm 9$ & $141 \pm 28$ & $*$ & ns & ns \\
\hline Betaine & $6.7 \pm 0.9$ & $8.9 \pm 1.8$ & $6.0 \pm 1.9$ & $3.2 \pm 1.2$ & ns & $\mathrm{ns}$ & $\mathrm{ns}$ \\
\hline Trigonelline & $70 \pm 11$ & $105 \pm 21$ & $26 \pm 2$ & $60 \pm 17$ & ns & $*$ & $\mathrm{~ns}$ \\
\hline
\end{tabular}

Table IV. Proline (nmol g ${ }^{-1}$ fresh mass) and proline analogues concentration in roots of E. globulus Clones CN5 and ST51 after cold acclimation (Day 1), after 7 and 42 days of sub-optimal temperature. CT - control $\left(24 / 16^{\circ} \mathrm{C}\right)$, SOT - suboptimal temperature $\left(10 / 5{ }^{\circ} \mathrm{C}\right) . *, * *, * * * \mathrm{Represent}$ statistical significance at $P<0.05,0.01$ and 0.001 , respectively; and ns $=$ nonsignificant at $P=0.05$.

\begin{tabular}{|c|c|c|c|c|c|c|c|}
\hline \multirow{2}{*}{$\begin{array}{l}\text { Days after } \\
\text { acclimation }\end{array}$} & \multirow[b]{2}{*}{ CN5 CT } & \multirow[b]{2}{*}{ ST51 CT } & \multirow[b]{2}{*}{ CN5 SOT } & \multirow[b]{2}{*}{ ST51 SOT } & \multicolumn{3}{|c|}{ Two-way ANOVA } \\
\hline & & & & & Clone (C) & Temp.(T) & $\mathrm{C} \times \mathrm{T}$ \\
\hline \multicolumn{8}{|l|}{ Day 1} \\
\hline Proline & $25.1 \pm 9$ & $8.5 \pm 1.5$ & $5.6 \pm 3,0$ & $9.4 \pm 0.7$ & ns & 0.07 & 0.054 \\
\hline Betaine & $12.9 \pm 2$ & $5.5 \pm 1.4$ & $5.6 \pm 0.6$ & $5.5 \pm 0.7$ & $* *$ & $* *$ & $* *$ \\
\hline Trigonelline & $5.9 \pm 2$ & $6.4 \pm 1.1$ & $6.1 \pm 0.7$ & $5.5 \pm 0.6$ & ns & $\mathrm{ns}$ & ns \\
\hline \multicolumn{8}{|l|}{ Day 7} \\
\hline Proline & $16.8 \pm 2$ & $15.2 \pm 3.5$ & $23.7 \pm 7$ & $49.3 \pm 18.5$ & ns & 0.06 & ns \\
\hline Betaine & $17.1 \pm 2$ & $11.7 \pm 1.6$ & $11.1 \pm 2.1$ & $11.4 \pm 0.09$ & ns & ns & ns \\
\hline Trigonelline & $19.8 \pm 3$ & $10.8 \pm 1.3$ & $20.7 \pm 2.1$ & $15 \pm 0.4$ & $* *$ & ns & ns \\
\hline \multicolumn{8}{|l|}{ Day 42} \\
\hline Proline & $13.1 \pm 1.6$ & $23.9 \pm 7.0$ & $10.8 \pm 2.6$ & $24.8 \pm 8.2$ & 0.055 & ns & ns \\
\hline Betaine & $15.3 \pm 1.8$ & $19.3 \pm 4.9$ & $13.4 \pm 2.3$ & $9.6 \pm 0.8$ & ns & ns & ns \\
\hline Trigonelline & $10.2 \pm 1.6$ & $10.3 \pm 1.1$ & $7.7 \pm 2.2$ & $5.2 \pm 0.8$ & ns & $*$ & ns \\
\hline
\end{tabular}

\section{DISCUSSION}

Our results showed that although both clones reduced growth in response to chilling, total root length of CN5 was significantly higher in comparison with ST51 in both control and treated plants. This was accompanied by a less negative predawn water potential and a higher leaf turgor in CN5 clone throughout the chilling treatment. This characteristic of CN5 plants will offer an advantage over the drought sensitive ST51 clone, not only under water-stress conditions, due to the possibility to explore more volume of soil [6], but also under cold temperatures through the benefits of higher new root regeneration.

The slowdown of growth during chilling was concomitant with an increase of carbohydrates in leaves and roots of both clones. Interestingly, it was observed at Day 1 , as a result of acclimation, an increase of content of glucose, sucrose and fructose in leaves of treated plants of both clones that disappeared later on. The increase in carbohydrates in leaves may reflect the reduction in the sink strength of the aboveground plant tissues. On the other hand, this will lead to more assimilates available for root growth.

Plant water status was not affected in chilled plants, as also observed in other species [8,33]. In fact, predawn water potentials were unaltered by chilling. Moreover, leaf turgor remained high in chilled plants of both clones, due to the decrease of osmotic potential as also observed in other $E u$ calytus species [29]. The degree of leaf osmotic adjustment given by $\Delta \psi_{\pi}^{100}$, was initially higher in CN5 comparatively to ST51 plants, in parallel with the higher sugars accumulation observed, but similar afterwards. In fact, a higher content of carbohydrates in leaves of CN5 chilled plants compared to ST51 was only observed at Day 1.

Acclimation of the photosynthetic apparatus to chilling and to high light is well documented but the mechanisms are not completely understood. Karpinska et al. [11] showed in Scots pine that chlorophyll synthesis is temperature sensitive, and under low non-freezing temperature it decreases, due to arrest of chloroplast biogenesis. According to our pigment analysis the same phenomena happened in both clones of E. globulus 
Table V. TFA ( $\mathrm{mg} \mathrm{g}^{-1}$ dry mass) and main fatty acids (mol \%) content in leaves of E. globulus Clones CN5 and ST51 after cold acclimation (Day 1), after 7 and 42 days of suboptimal temperature. CT - control $\left(24 / 16{ }^{\circ} \mathrm{C}\right)$, SOT - suboptimal temperature $\left(10 / 5{ }^{\circ} \mathrm{C}\right) . *, * *, * * *$ Represent statistical significance at $P<0.05,0.01$ and 0.001 , respectively; and ns $=$ nonsignificant at $P=0.05$.

\begin{tabular}{|c|c|c|c|c|c|c|c|}
\hline \multirow{2}{*}{$\begin{array}{l}\text { Days after } \\
\text { acclimation }\end{array}$} & \multirow[b]{2}{*}{ CN5 CT } & \multirow[b]{2}{*}{ ST51 CT } & \multirow[b]{2}{*}{ CN5 SOT } & \multirow[b]{2}{*}{ ST51 SOT } & \multicolumn{3}{|c|}{ Two-way ANOVA } \\
\hline & & & & & Clone (C) & Temp. (T) & $\mathrm{C} \times \mathrm{T}$ \\
\hline \multicolumn{8}{|l|}{$\overline{\text { Day } 1}$} \\
\hline TFA & $18.1 \pm 1.8$ & $22.3 \pm 2.5$ & $25.3 \pm 1.7$ & $20.8 \pm 1.7$ & ns & ns & $*$ \\
\hline $\mathrm{C} 16: 0$ & $28.2 \pm 0.9$ & $22.8 \pm 1.2$ & $25.4 \pm 1.0$ & $24.2 \pm 1.9$ & $*$ & ns & ns \\
\hline $\mathrm{C} 16: 1 t$ & $3.5 \pm 0.2$ & $3.0 \pm 0.4$ & $3.1 \pm 0.2$ & $2.7 \pm 0.4$ & ns & ns & ns \\
\hline C18:2 & $14.6 \pm 0.5$ & $14.9 \pm 0.5$ & $13.9 \pm 0.6$ & $16.9 \pm 0.6$ & $*$ & ns & $*$ \\
\hline $\mathrm{C} 18: 3$ & $44.8 \pm 1.5$ & $54.0 \pm 1.3$ & $51.1 \pm 1.4$ & $50.7 \pm 2.4$ & $*$ & ns & $*$ \\
\hline \multicolumn{8}{|l|}{ Day 7} \\
\hline TFA & $22.7 \pm 1.8$ & $20.6 \pm 2.1$ & $18.8 \pm 0.9$ & $24.5 \pm 2.4$ & ns & ns & ns \\
\hline C16:0 & $23.0 \pm 0.2$ & $20.9 \pm 0.8$ & $23.9 \pm 0.9$ & $25.0 \pm 1.5$ & ns & $*$ & ns \\
\hline $\mathrm{C} 16: 1 t$ & $3.4 \pm 0.3$ & $3.5 \pm 0.1$ & $4.0 \pm 0.2$ & $3.1 \pm 0.4$ & ns & ns & ns \\
\hline C18:2 & $10.7 \pm 0.4$ & $12.9 \pm 0.2$ & $15.5 \pm 1.2$ & $17.6 \pm 1.3$ & $*$ & $* * *$ & ns \\
\hline C18:3 & $56.3 \pm 0.6$ & $57.3 \pm 0.8$ & $49.1 \pm 1.5$ & $49.1 \pm 2.0$ & ns & $* * *$ & ns \\
\hline \multicolumn{8}{|l|}{$\overline{\text { Day } 42}$} \\
\hline TFA & $14.7 \pm 0.6$ & $18.9 \pm 1.6$ & $17.3 \pm 0.4$ & $17.3 \pm 2.0$ & ns & ns & ns \\
\hline C16:0 & $21.3 \pm 0.6$ & $19.2 \pm 0.8$ & $22.4 \pm 0.5$ & $25.4 \pm 1.4$ & ns & $* *$ & $*$ \\
\hline C16:1t & $3.01 \pm 0.2$ & $2.8 \pm 0.3$ & $3.0 \pm 0.1$ & $2.5 \pm 0.3$ & ns & ns & ns \\
\hline C18:2 & $12.2 \pm 0.2$ & $11.8 \pm 0.9$ & $16.0 \pm 0.7$ & $15.4 \pm 0.4$ & ns & $* * *$ & ns \\
\hline C18:3 & $57.1 \pm 0.8$ & $61.8 \pm 1.9$ & $53.9 \pm 0.8$ & $52.7 \pm 2.2$ & ns & $* *$ & ns \\
\hline
\end{tabular}

Table VI. TFA ( $\mathrm{mg} \mathrm{g}^{-1}$ fresh mass) and main fatty acids (mol \%) content in roots of E. globulus Clones CN5 and ST51 after cold acclimation (Day 1), after 7 and 42 days of sub-optimal temperature. CT - control $\left(24 / 16^{\circ} \mathrm{C}\right)$, SOT - suboptimal temperature $\left(10 / 5{ }^{\circ} \mathrm{C}\right), *{ }^{*} * * * * * \mathrm{Represent}$ statistical significance at $P<0.05,0.01$ and 0.001 , respectively; and ns $=$ nonsignificant at $P=0.05$.

\begin{tabular}{|c|c|c|c|c|c|c|c|}
\hline \multirow{2}{*}{$\begin{array}{l}\text { Days after } \\
\text { acclimation }\end{array}$} & \multirow[b]{2}{*}{ CN5 CT } & \multirow[b]{2}{*}{ ST51 CT } & \multirow[b]{2}{*}{ CN5 SOT } & \multirow[b]{2}{*}{ ST51 SOT } & \multicolumn{3}{|c|}{ Two-way ANOVA } \\
\hline & & & & & Clone $(\mathrm{C})$ & Temp. (T) & $\mathrm{C} \times \mathrm{T}$ \\
\hline \multicolumn{8}{|l|}{$\overline{\text { Day } 1}$} \\
\hline TFA & $1.40 \pm 0.13$ & $1.10 \pm 0.11$ & $1.20 \pm 0.08$ & $1.32 \pm 0.14$ & ns & ns & ns \\
\hline $\mathrm{C} 16: 0$ & $32.1 \pm 1.1$ & $29.5 \pm 2.0$ & $28.1 \pm 0.7$ & $27.8 \pm 0.4$ & ns & $*$ & ns \\
\hline C18:2 & $51.3 \pm 2.3$ & $54.5 \pm 1.6$ & $55.8 \pm 0.9$ & $55.4 \pm 0.3$ & ns & ns & ns \\
\hline C18:3 & $7.3 \pm 0.6$ & $7.8 \pm 0.3$ & $9.0 \pm 0.5$ & $10.0 \pm 0.6$ & ns & $* *$ & ns \\
\hline \multicolumn{8}{|l|}{$\overline{\text { Day } 7}$} \\
\hline TFA & $0.75 \pm 0.08$ & $1.09 \pm 0.11$ & $1.47 \pm 0.05$ & $1.20 \pm 0.17$ & ns & $* *$ & $*$ \\
\hline C16:0 & $30.2 \pm 1.6$ & $28.3 \pm 0.7$ & $29.6 \pm 0.7$ & $31.3 \pm 0.6$ & ns & ns & ns \\
\hline C18:2 & $49.3 \pm 2.1$ & $52.4 \pm 1.4$ & $51.9 \pm 0.7$ & $50.2 \pm 1$ & ns & ns & ns \\
\hline C18:3 & $11.5 \pm 2.1$ & $11.0 \pm 1.9$ & $12.6 \pm 0.9$ & $12.5 \pm 1.0$ & ns & ns & ns \\
\hline \multicolumn{8}{|l|}{$\overline{\text { Day } 42}$} \\
\hline TFA & $1.08 \pm 0.10$ & $1.42 \pm 0.08$ & $1.82 \pm 0.11$ & $1.51 \pm 0.05$ & ns & $* * *$ & $* *$ \\
\hline C16:0 & $33.6 \pm 1.4$ & $31.4 \pm 0.5$ & $30.8 \pm 0.8$ & $30.7 \pm 0.9$ & ns & ns & ns \\
\hline C18:2 & $46.4 \pm 2.2$ & $49.9 \pm 0.4$ & $52.0 \pm 0.9$ & $50.4 \pm 1.1$ & ns & $*$ & ns \\
\hline C18:3 & $10.9 \pm 0.8$ & $10.6 \pm 0.3$ & $11.8 \pm 0.4$ & $13.0 \pm 0.7$ & ns & $*$ & ns \\
\hline
\end{tabular}

with higher reduction in ST51 plants; the same occurred as far as fucoxanthine, lutein and $\beta$-carotene is concerned. We can hypothesize that ST51 plants suffered more under suboptimal temperatures.

Our data also showed that the amount of proteins in clone ST51 after 42 days of chilling was reduced drastically, which may have a negative impact in the long term response of this clone to suboptimal temperatures. This was not the case for clone CN5.

The role of osmoprotectants along with carbohydrates has also been frequently assigned to proline [9], although, some authors have considered proline accumulation as a symptom of damage rather than an adaptive response [19]. On the other hand, proline contribution to osmoregulation is small in most cultivated species under stress conditions [28]. This was also the case with the E. globulus clones under water stress, in which the contribution of this amino acid to the osmotic potential was around $1 \%$ [24]. In the present study the lower values of $\psi_{\pi}$ in leaves under chilling temperatures observed in both clones were not accompanied by proline accumulation either in leaves and roots. This suggests that proline did not act as a relevant active osmolite in Eucalyptus tissues under suboptimal temperatures. However proline and its analogues may be associated with other roles under stress conditions: protection 
of cytosolic enzymes and membrane structure, stabilisation of proteins, antioxidant and storage functions [23,25] and these roles are not ruled out. In this respect the higher values of proline observed in CN5 leaves may play a positive role in growth under low temperatures.

The unsaturation of membrane lipids is considered a critical parameter for the functioning of plant membranes. Membrane lipids may suffer changes with growth temperature, particularly in what concerns linolenic acid (C18:3) [5]. An increase of unsaturation may compensate the decrease in the fluidity of membrane that is brought about by the downward shift in temperature [21], and therefore sustained activity of membranebound enzymes at lower temperature.

At the beginning of chilling treatment (Day 1), an increased lipid amount (TFA) and a concomitant increase of C18:3 percentage were observed in CN5 leaves, probably due to an activation of lipid synthesis resulting in more unsaturated lipid molecular species. A higher degree of unsaturation could increase membrane fluidity and constitute an advantage for leaves of CN5 clone under cold conditions. The fact that TFA amounts were not reduced by cold stress suggests that molecular adaptation of lipids occurs apparently without lipid loss, resulting in a decrease of membrane unsaturation.

In roots a higher degree of unsaturation (as inferred from the increase in C18:3 percentage) was observed in treated plants of both clones, which may depend on compositional changes resulting from lipid turnover [22]. An enhanced lipid synthesis in CN5 roots was observed but not in ST51, suggesting a better preservation of root metabolism in CN5 under low temperature.

In summary, our data showed that both CN5 and ST51 E. globulus clones have the ability to acclimate to chilling temperatures. Changes, observed in carbohydrates and membrane lipid content following acclimation may play a role in the resistance of $E$. globulus to chilling. Differences between clones were observed in soluble protein and pigment content which were more stable in CN5 than ST51 under chilling temperatures. It also was apparent that $\mathrm{CN} 5$ presented a less negative predawn water potential $\left(\psi_{\mathrm{pd}}\right)$ and a higher leaf turgor than ST51 throughout the chilling treatment. As a result of acclimation, an increase of total lipids (TFA) and concomitant increase of $\mathrm{C} 18: 3$ in leaves of CN5 clone may confer to this clone a better performance under chilling temperatures. Although clone CN5 did not present a higher growth under chilling relative to ST51, it showed a lower inhibition of root growth and a greater carbon allocation to roots.

Acknowledgements: Shvaleva A. was supported by FCT, Lisbon (Grant SFRH/BPD/5667/2001) and Costa e Silva F. by FCT, Lisbon (Grant SFRH/BD/13211/2003). The authors thank to Dr. Colin Mc Vey for English revision of the manuscript and for Viveiros Aliança for providing the plant material.

\section{REFERENCES}

[1] Allen C.F., Good P., Davis H.S., Chisum P., Fowler S.D., Methodology for the separation of plant lipids and application to spinach leaf and chloroplast lamellae, J. Am. Oil Chem. Soc. 43 (1966) 223-230.

[2] Almeida M.H., Chaves M.M., Silva J.C., Cold acclimation in eucalypt hybrids, Tree Physiol. 14 (1994) 921-932.

[3] Bradford M.N., A rapid and sensitive method for the quantification of microgram quantities of protein utilizing the principle of proteindye binding, Anal. Biochem. 72 (1976) 248-254.

[4] Chaves M.M., Pereira J.S., Maroco J.P., Understanding plant response to drought - from gene to the whole plant, Funct. Plant Biol. 30 (2003) 1-26.

[5] Cossins A.R., Homeoviscous adaptation of biological membranes and its functional significance, in: Cossins A.R. (Ed.), Temperature Adaptation of Biological Membranes, Portland Press, London, 1994, pp. 63-76.

[6] Costa e Silva F., Shvaleva A, Maroco J.P., Almeida M.H., Chaves M.M., Pereira J.S., Response to water stress in two Eucalyptus globulus clones differing in drought tolerance, Tree Physiol. 24 (2004) $1165-1172$.

[7] Easterling D.R., Meehl G.A, Parmesan C., Changnon S.A., Karl T.R., Mearns L.O., Climate extremes: observations, modeling, and impacts, Science 289 (2000) 2068-2074.

[8] Equiza M.A., Mirave J.P., Tognetti J.A., Morphological, anatomical and physiological responses related to differential shoot vs. root growth inhibition at low temperature in spring and winter wheat, Ann. Bot. 87 (2001) 67-76.

[9] Gibon, Y., Ronan S., Larher F., Proline accumulation in canola leaf discs subjected to osmotic stress in related to the loss of chlorophylls and to the decrease of mitochondrial activity, Physiol. Plant. 110 (2000) 469-476.

[10] Guignard C., Jouve L., Bogeat-Triboulot M.B., Dreyer E., Hausman J.-F., Hoffmann L., Analysis of carbohydrates in plants by highperformance anion-exchange chromatography coupled with electrospray mass spectrometry, J. Chromatogr. 1085 (2005) 137-42.

[11] Karpinska B., Karpinski S., Krol M., Hällgren J.F., Developmental regulation of light independent transcription of nuclear and plastid encoded chloroplast proteins in Scots pine, in: Mathis P. (Ed.), Photosynthesis: from light to biosphere, Kluwer Acad. Publishers, Dordrecht, 1995, pp. 571-574.

[12] Levitt J., Responses of plants to environmental stresses: chilling, freezing and high temperature stresses, 2nd ed., Academic Press, New York, 1980.

[13] Lyons J.M., Chilling injury in plants, Ann. Rev. Plant Physiol. 24 (1973) 445-466.

[14] Metcalfe L.D., Schemitz A.A., Pelka J.R., Rapid preparation of fatty-acid esters from lipids for gas chromatographic analysis, Anal. Chem. 38 (1966) 514-515.

[15] Miranda P.M.A., Valente M.A., Tomé A.R., Trigo R., Coelho M.F., Aguiar A., Azevedo E.B., O clima de Portugal nos séculos XX e XXI, in: Santos F.D., Miranda P. (Eds), Alterações Climáticas em Portugal. Cenários, Impactes e Medidas de Adaptação, Gradiva, Lisboa, 2006, pp. 45-113.

[16] Murata N., Ishizaki-Nishizawa O., Higashi S., Hayashi H., Tasaka Y., Nishida I., Genetically engineered alteration in the chilling sensitivity of plants, Nature 356 (1992) 710-713.

[17] Naidu B.P., Separation of sugars, polyols, proline analogues, and betaines in stressed plant extracts by high performance liquid chromatography and quantification by ultra violet detection, Aust. J. Plant

[18] Oufir M., Schulz N., Sha Valli Khan P.S., Wilhelm E., Burg k., Hausman J.F., Hoffmann L., Guignard C., Analysis of proline, glycine betaine analogues and quaternary ammonium compounds in plants by high-performance ligand-exchange chromatography coupled with electrospray mass spectrometry for environmental stress studies, submitted to J. Chrom. A (2008). 
[19] Pérez-Alfocea F., Santa-Cruz A., Guerrier G., Bolarin M.C., $\mathrm{NaCl}$ stress-induced organic solute changes on leaves and calli of Lycopersicon esculentum L. pennelli and their interspecific hydrofit, J. Plant Physiol. 143 (1994) 106-111.

[20] Pham Thi A.T., Borrel-Flood C., Vieira da Silva J., Justin A.M., Mazliak P., Effects of water stress on lipid metabolism in cotton leaves, Phytochem. 24 (1985) 723-727.

[21] Raison J.K., The influence of temperature-induced phase changes on kinetics of respiratory and other membrane-associated enzymes, J. Bioenerg. 4 (1973) 258-309.

[22] Scotti Campos P., Quartin V., Ramalho J.C., Nunes M.A., Electrolyte leakage and lipid degradation account for cold sensitivity in leaves of Coffea sp. plants, J. Plant Physiol. 160 (2003) 283-292.

[23] Shomer-Ilan A, Jones G.P., Paleg L.G., In vitro thermal and salt stability of pyruvate kinase are increased by proline analogs and trigonelline, Aust. J. Plant Physiol. 18 (1991) 279-286.

[24] Shvaleva A., Costa e Silva F., Breia E., Jouve L., Hausman J-F., Almeida M.H., Maroco J.P., Rodrigues M.L., Chaves M.M., Pereira J.S., Metabolic response to water deficit in two Eucalyptus globulus L. clones with contrasting drought sensitivity, Tree Physiol. 26 (2006) 239-248.

[25] Smirnoff N., Environment and plant metabolism: flexibility and acclimation, Univ. Lancaster, UK, 1996.

[26] Somerville C., Direct tests of the role of membrane lipid composition in low-temperature-induced photoinhibition and chilling sensitivity in plants and cyanobacteria, Proc. Natl. Acad. Sci. 92 (1995) 6215-6218. Physiol. 25 (1998) 793-800.

[27] Steponkus P.L., Role of the plasma-membrane in freezing-injury and cold-acclimation, Ann. Rev. Plant Physiol. Plant Mol. Biol. 35 (1984) 543-584.

[28] Taylor C.B., Proline and water deficit. Ups, downs, ins and outs, Plant Cell, 8 (1996) 1221-1224.

[29] Valentini R., Scarascia Mugnozza G., Giordano E., Kuzminsky E., Influence of cold hardening on water relations of three Eucalyptus species, Tree Physiol. 6 (1990) 1-10.

[30] Van Huylenbroeck J.M., Debergh P.C., Physiological aspects in acclimatization of micropopagated plants, Plant Tissue Culture Biotechnol. 2 (1996) 136-141.

[31] Wilson L., Amy C., Gordon H., Johnson B., Miller J., Water quality changes during soil aquifer treatment of tertiary effluent, Water Environ. Res. 67 (1995) 371-376.

[32] Wright S.W., Jeffrey S.W., Mantoura R.F.C., Llewellyn C.A., Bornland T., Repta D., Welschmeyer N., Improved HPLC method for the analysis of chlorophylls and carotenoids from marine phytoplankton, Marine Ecol. Progress Series, 77 (1991) 183-196.

[33] Woodward F.I., Friend A.D., Controlled environment studies on the temperature responses of leaf extension in species of Pea with diverse altitudinal ranges, J. Exp. Bot. 39 (1988) 411-420. 